\title{
Exemplary Cities in China: The Capitalist Aesthetic and the Loss of Space
}

\author{
Carolyn Cartier
}

\begin{abstract}
Since the late twentieth century, the subject of China becoming urban has appeared in the scholarship across the disciplines while spectacular images of China's cities, and narratives about their developmental achievements, have proliferated in global media. At the same time, the parallel "spatial turn" in social thought invigorated geographical approaches to cities and urban change. Yet at this promising meeting ground, between contemporary geographical thought and urban-industrial transformation in China, research has tended to demonstrate a "loss of space" through patterns of dependence on analog circulation of exemplar paradigms that derive from the history of the capitalist city and liberal political economy. What drives this condition and what do we know about its practices and proliferation? This inquiry challenges research design and the politics of theory to consider how routine adoption of capital-centric concepts for research on cities in China arguably reflects the priority of paradigms in the disciplines and their conjunctures with exemplarity in Chinese society and political philosophy. These interstices facilitate application of analog models, and selective adoption of empirical information to suit them, with the paradoxical result of portraying cities in China through multiple capitalist aesthetics including a relatively narrow range of empirics framed by market-based social thought.

Contact: Carolyn Cartier, Carolyn.Cartier@uts.edu.au, School of International Studies, University of Technology Sydney, Australia.
\end{abstract}




\section{Introduction}

In September 2011 when New Yorkers initiated "Occupy Wall Street”- the mass movement against social and economic inequality—and declared, "We are the 99\%," people in Henan province in north China were among the first to respond in solidarity. In the cities of Luoyang and Zhengzhou, retirees and some local Chinese Communist Party members gathered in support of the New Yorkers demonstrating in Zuccotti Park. In Zhengzhou they raised the banner “坚决支持美国人民伟大的华尔街革命” (Resolutely Support the American People's Great Wall Street Revolution). The short-lived response in Henan emerged in the style of slogans and banners that characterized mass movements of the Mao era, 1949-1976 (Wu 2011). Such revolutionary sentiments in China and goals of the Occupy movement in the United States generate from significantly different histories of political and economic experience. But through space-time distanciation, and a few Internet memes, once incommensurable places even in provincial China now interrelate, juxtapose, and resonate with global events in unexpected ways.

The mediascape of China becoming urban, significant and sensational, circulates spectacles that attract worldwide interest. These include many "mosts" and "largests" such as one of the largest new buildings in the world, in Chengdu, and the most recent replica of the Eiffel Tower, in suburban Hangzhou. But the contemporary Chinese city distinctively marks the history of urban modernity because its human dimension paradoxically emerges in speed: urbanization in China is taking place not in centuries but in decades of human lifetime. People directly witness the vast scale and scope of its materialization. And yet the significance of urbanization in China, despite extensive scholarship, arguably continues to be incommensurable with understanding. Even the 
names of these major regional centers of millions of people — Chengdu and Hangzhou— among the most famous cities in China, elicit little recognition outside specialist scholarship. Luoyang too is only provincial in the absence of history: it was a recurring imperial capital for more than 1500 years. The reach of urban history alone in China challenges temporal baselines in comparative urban inquiry.

The potential of different histories of urban development are more than questions of culture and development, more than the always-problematic binaries of east/west, west/the rest/ or west/China. They are questions about intersections and meeting grounds of ideas traveling in the world within and among disciplines and national academies, and through the ideal of the international academy — questions that lead to explanations about urbanizing China that demonstrate new insights and confidences yet simultaneously continue to occlude, bracket, and mystify what is "variegated" about China in the sense of more than variation in economic conditions as national or regional archetypes.

This discussion seeks to take the measure of possibilities and incommensurabilities in research on cities in China through questions about research design and the uses of paradigms and theory in disciplinary and interdisciplinary work. It takes a historical approach in order to locate conditions of epistemological disjuncture and to assess what constitutes their gaps and whether and in what ways they might be bridged. Its analysis builds on arguments developed by Wing Shing Tang (2014), who identifies in the literature "random conceptual appropriation" of western theories and concepts, including neoliberal urbanism, gentrification, gated community, enclave urbanism, right to the city, and so on, and their "random conceptual indigenization" through anodyne modifiers like "state-led" and passing references to government and related elocutions that, through minimal discursive 
modification, elide powers and agency of the party-state. By "random" I take Tang to mean adoption of concepts simply because they already exist and appear suitable, confirmed by publication in international English-language journals, and, through indigenization by selective use of empirics yet without identification of conditions that differ from those embedded in the adopted theory, and how those conditions would compel a dialectical analysis - a dialectics of theory and empirics — for consequent innovation of theoretical work. Together these conditions and their limitations confirm and reproduce the priority of disciplinary theory and, often, western theoretical baselines in history and political economy.

The discussion first situates geography in historical-global relations of scientific modernity and disciplinary paradigms and models, inclusive of China, where the development of tertiary education and university research are fundamental to the modernization project. The classic problem with scientific paradigms, following the Kuhnian thesis, is that they do not serve as incisive analytical tools but as exemplars, i.e. their explanatory elements are not evaluated for their limitations and adjusted for new situations, with the result that their applications in places whose empirics do not confirm their existing elements pivot on bracketing the different conditions or adjusting empirics to accommodate the paradigm. Analog logic, i.e. circulation and repetitive adoption of the paradigm, finds parallels of analog models in Chinese society and political-economic thought, past and present, including models for exemplary conduct and achievement. The party-state promotion of heuristic models and, through them, specification of standards in China, combined with neoliberalizing mandates for quantities of international publications, worldwide, contributes to the circulation of exemplar paradigms in scientific research, including urbanization. This intersection of models supports adoption 
of western qua international paradigms that confer on urban and regional research in China less about accounts of historical conditions and Chinese political economy than interpretations refracted through the priority of models whose reproduction accumulates in a "loss of space" about geographies in China.

By "loss of space" I mean the passing over and leaving out urban geographies of context and potential ideas about them. These contexts are more than changing local conditions or notional empirics; they are also general conditions of geographies driving the political economy that do not "fit" the normative paradigms. The "loss of space" sees this disregard of material histories and their ideational potentials spurred by adoption of formulaic exemplars. Especially in the journal literature, partial representations, and some inaccurate ones, leave China written in terms of internationalized theoryspectacular, neoliberal, and entrepreneurial. The iterative and repetitive nature of the practice of matching China to analog models yields only a refracted version of China. As Tim Oakes writes, in this issue, "urban China has come into academic and popular media focus in a way that often isolates it from China's own historical, social, and political contexts." This problem reflects in part geography's disciplinary history and traditions.

\section{Science and geography}

Across the spectrum of human and physical geography, geography demonstrates an international history of dedication to science and scientific practice (Martin 2015). Yes, theoretical advances in human geography have laid bare the limits of positivism and propelled a theoretical rejuvenation in spatial thought in the discipline (Soja 1989). Its conceptual leadership has exposed the limits of the fixed-space approaches, especially the 
“container" of methodological nationalism (Agnew 1987), which has plagued the social sciences at large (Wimmer and Schiller 2002). Geography has proved to be especially adroit at handling scale relations and the messy meso-scale of cities and regions, which are the contexts of economic agglomeration in the current global age. Nevertheless, it remains that the ideal and mission of science has prevailed in statements of the flagship geographical organizations across the continents.

The national geographical societies were established to pursue knowledge of the new and the legitimacy of scientific discovery—exploration, documentation, and classification. They formed in the nineteenth century when rising industrial powers sought economic frontiers and supported expeditions to the ends of the Earth. The Société de Géographie emerged first, in Paris, in 1821, followed by the Berlin Geographical Society in 1828. In Britain, the Royal Geographical Society, chartered by Queen Victoria in 1859 , began as a private club in 1830 . The National Geographic Society, organized in Washington, D.C. in 1888, gained popularity through dissemination of scientific maps. In debate over whether to search for the lost Arctic expedition of Sir John Franklin, which sought the Northwest Passage, elite explorers in New York formed the American Geographical Society in 1851. Only the Swedish Society for Anthropology and Geography, founded in 1877, was interdisciplinary from the start. In China, Zhang Xiangwen organized the first professional geographical organization, the Geoscience Society of China, in Tianjin, in 1909, and Zhu Kezhen led the founding of the Geographical Society of China, in Nanjing, in 1934. With establishment of the People's Republic of China (PRC) in 1949 and subsequent reorganization of academic institutions 
under the Chinese Communist Party (CCP), the two organizations were merged to form the current Geographical Society of China.

All these institutions, to the present, have explicitly supported geographical science. The Royal Geographical Society's “purpose remains the same today as when it was founded, namely 'the advancement of geographical science"” (The Royal Geographical Society, n.d.). The objective of the Geographical Society of China (2018) “aims at promoting scientific research...popularizing national geographical knowledge...making contributions to the socialist modernization drive, and developing socialist material and spiritual civilization." This expansive agenda incorporates the central mission of the PRC, the socialist modernization drive, and the core language, developing socialist material and spiritual civilization, of the party-state's general political thought program. The standard term party-state indicates in the unitary state formation that is in the PRC the power of the CCP over the government at all levels. Consider first the language of the objectives of the Geographical Society of China. The typical international analysis elides the socialist political thought language. Spiritual civilization or jingshen wenming (精神文明) is a core concept in CCP thought work. Core party concepts like spiritual civilization appear in the Chinese-language journal literature, but do not, reflecting "international" paradigms, feature with any reliability in the disciplinary geography literature. Where international knowledge now identifies matters of authoritarian functionality in the PRC, like the all-state media and controls on the Internet, party-state governance of information is a more complex programmatic arena, both domestic and international, under administration of the Xuanchuanbu 宣传部, the Propaganda Department, also translated as the Publicity 
Department. Spiritual civilization is one of its umbrella concepts, featuring in party-state policy for cities, state industries, and the education system. In the 1990s, "patriotic education was formally designated as 'the main task of spiritual civilization work"” (Brady 2009, 50). Spiritual civilization work also serves as a policy program for city governance, which I return to assess in this discussion.

The contribution of geographical research to development and modernization in China extends a long history of geography in service to the state. Activity of the Royal Geographical Society was closely bound up with British colonialism (Barnett 1998; Barrow 2004). French and German universities opened the first departments of geography after the Franco-Prussian War, emphasizing geographical knowledge for military preparedness (Hudson 1977). German geography developed location theories to plan settlement and industrialization in support of state strengthening, under the Third Reich (Barnes and Minca 2013). About the United States, as Neil Smith narrates, in American Empire, geographers worked in service to the government's geopolitical interests. From World War II, "marked by tense and intense communication between German and U.S. geographers," to the Cold War and the World Trade Organization, geographical thought in the United States informed strategic state interests in "the global geography of the American Empire" (Smith 2004, 275; 456). In American twentieth century geopolitics, Smith observes "little critical difference between academic geography and national policy" (282).

Geography's capacity to inform national development and industrial modernization has shifted across the Pacific. The record of geographical scholarship about China makes evident the close relationship between national development and 
geographical research in the PRC (Fan, Ma, Pannell and Tan, 2002). Since the PRC opened to the world economy in the 1980s, the fields of economic geography, urban geography, and urban and regional planning have defined and dominated the geographical scholarship. The late industrialization of China has made its economy and urbanization the overriding subjects of domestic planning and research as well as international inquiry. On the domestic front, in addition to national research funding opportunities, province and city governments maintain funding programs for local applied research, and, similar to the history of other industrial powers, geographers in China's era of industrialization also consult for government. China's interests, capacities, and impacts have made its urbanization and economic development the normative subjects of geographical inquiry for three decades.

Research on the relationship between scientific modernization and geographical knowledge production in China, in the manner of Smith's work in American Empire, awaits future scholarly inquiry. We can note a few points of departure. The priority of scientific modernization compelled departments of geography in major universities to demonstrate commitment - by changing their names. There was an international petition against the change, led by Zhou Yixing, faculty member in the Department of Geography at Peking University (the conventional name of Beijing University), and Laurence J. C. Ma, in Geography at Akron University, when it became known that the university would change the name of the Department of Geography. Geography in Peking University is now Urban and Environmental Sciences. In Shanghai, East China Normal University has developed a Faculty of Earth Sciences with four departments in which three focus on the physical environment and one is the School of Urban and Regional Sciences. The 
national significance of urban and regional development in China makes research on cities and economic regions an expansive scientific enterprise.

The imperative of science has only intensified since 2012 under the leadership of Xi Jinping, General Secretary of the CCP and President of the PRC. His recent speeches, in 2018, for instance, continue to trumpet "scientific, technological, and industrial revolutions." As China's state news agency, Xinhua (2018), reports, at the $19^{\text {th }}$ Meeting of the Academicians of the Chinese Academy of Sciences, in Beijing, "Xi urged courageous moves to reach for the 'commanding heights' in scientific and technological competition and future development." Especially the national-level universities (the highest-ranking universities, located around the country), under the direct leadership of the Ministry of Education, champion state directives and goals, and compete to attain and lead international standards.

\section{Paradigms and politics}

The challenges and complexities of research on urban China also reflect tensions between scholarly fields, especially those between the disciplines and specialist China research in area studies. At their crossroads, debate periodically surges around the relationship between theory (as if only disciplines articulate it) and empirics (as if China studies' singular utility). Contrary to typical assumptions in the disciplines, the adoption of scientific paradigms has also characterized China studies. Historically, these include applications of scientific Marxism and adaptations of spatial science models to analysis of regions in China.

My interest in the problems of paradigms in the epistemologies of knowledge emerged with the realization that research on cities and towns in China studies depended 
on outmoded paradigms in mid-century location theory and spatial science (Cartier 2002). Indeed, when the China field in the United States first adopted location theory for research on cities, in the 1960s, it was in response to institutional pressures for the advancement of social science. G. William Skinner, a sociological anthropologist who occupied leadership positions in the U.S. academy, developed the model of "macroregions" from central place theory and urban and regional systems theory. The model defines nine spatially bounded watershed regions in which, presumptively, separate urban systems developed and, thus, in which scholars would locate their work. In a review of the field, Judith Farquahar and James Hevia $(1993,496)$ characterize Skinner's "regional-market systems approach" as "a ruling organizational paradigm for social history in China." It is this role of paradigms operating sociologically as a "grouplicensed way of seeing" that Thomas Kuhn $(1962,189)$ identified in his classic analysis, The Structure of Scientific Revolutions. If scholars learn the paradigm socially, e.g. their colleagues or professors insist on its importance and so on, rather than analytically, through discerning analysis, the routine adoption of the paradigm continues without questioning, and in many cases without understanding its fundamental elements.

Skinner published the model in the late 1970s, yet by this time location theory was becoming superseded in geography. From the ensuing divergence between geographical theory and China studies, the specialty field has never recovered conceptual leadership. The China field's prolonged devotion to its group optic of fixed regions arguably resulted in both limited interpretations of space and periodic returns to the foundry of geographical thought in which Skinner originally discovered the ore for his model. This is evident in the literature related to the 1990s-era spatial turn. Prominent 
books on urbanizing China featured new visions of space as a total concept, i.e. without warranted engagement of interrelated interpretations and ideas including landscape, place, and territory (cf. Li 2003; Yang 1999). In the wave of the poststructuralist shift in social thought, the spatial turn witnessed a variety of approaches. Some over-determined the idea of space and continued to treat space as merely bounded or fixed areas.

Even the dominant disciplinary partners of China research, namely economics, history, political science, and sociology, adopted the macroregion model. By treating river basin regions as fixed territories, the model effectively scales-down the territorial container embedded in the nation-state model. Indeed, an infrequent conceit of the core social sciences disciplines is their dependence on a naturalized nation-state paradigm (Cooper and Packard 1997; Walder 2004). The priority of bounded spaces in the geographical imagination belies the existence of dynamic spatial processes in urban and regional formation. Geography's command of ideas at the meso-scale ascended in the late twentieth century as the liberal state's Keynesian-era nation-space yielded to city-region governance in networked global economies.

Certainly, normative theory freights any disciplinary research train. But the problem is not theory per se; the problem is un-reflective uses of paradigms in research design. At the height of the challenge to the nation-state as a "container" of knowledge during the poststructuralist shift in the 1990s, Arif Dirlik, a historian of China's political economy, invoked the work of philosopher Paul Feyerabend to articulate a metaargument about the relations between theory and empirics: 
Facts and theories are much more intimately connected than is admitted by the autonomy principle or 'positivist scientific practice' - the principle that facts exist and are available independently of whether or not one considers the ideological context and alternatives to the theory to be assessed. Not only is the description of every single fact dependent on some theory...but there also exist facts which cannot be unearthed except with the help of theory, and which become unavailable as soon as such alternatives are excluded (Feyerabend as quoted in Dirlik 1996, 246-247).

With this challenge, Dirlik identifies the problem of asserting facts and sheltering them under methodological claims of scientific practice. The issue Dirlik identifies is the adoption of research paradigms, including the macroregion, as if scientific without understanding their theoretical elements and implications - and their politics. There was a context in the American academy. As the United States industrialized to global prominence after the Second World War, not unlike China today, the social sciences came under acute pressure to demonstrate quality, merit, and utility through adoption of scientific models (Geiger 1993; Atkinson and Blanpied 2008). In the Cold War era, liberal market ideology especially characterized the normative models. The scientific imperative marched ahead with the highpoint of postwar American industrial capitalism.

That the selection of empirical material in itself also depends on seeing through the lens of theory, acknowledged or not, advances another level of challenge. That existing sets of facts may represent particular paradigms or may be ideologically cast, imbued with bias, can pre-populate with politics what would be objective practice. 
Certainly, this reality may be more apparent since "alternative facts" entered the mediascape, i.e. associated with the discourse of the $45^{\text {th }}$ President of the United States. Can we reliably conduct academic research with recognition of our own worldviews, and interrogate our own potential biases?

State statistical projects can be emblematic of these issues. In the 1950s, state formation in China under the People's Republic sought to classify minority groups which followed, in several ways, the approach developed in the Soviet Union (cf. Hirsch 2005). The field survey, supported by scientific work of ethnologists and linguists, ultimately resulted in official recognition of 55 groups in the PRC. Most are in large territorial areas in the west and northern and southern border regions, but they constitute only a fraction of the more than 400 ethno-linguistic groups identified in the research work (Mullaney 2010). Neither the diversity of national minorities nor the stability of their cultures and livelihoods would be the scientific priority in advancing territorial governance.

\section{Exemplar paradigms}

In contrast to the disciplines of history, economics, political science, and sociology, geography and anthropology have attained a certain breakthrough status in research on China because their epistemological advances grapple with dynamics between and among local, national, and global conditions. In lines of inquiry that trace from David Harvey's (1978) early theoretical work on the urban process under capitalism right up to the present, urban and economic geography have prominently demonstrated capacity to frame questions about precisely the predominant changes at stake in contemporary China - urbanization and development of cities and regions. Fulong Wu's first article in 
the International Journal of Urban and Regional Research, for example, is an interpretation of property rights and Harvey's thesis of the urban process for $\mathrm{China}(\mathrm{Wu}$ 1997). Urbanization in China underpins the country's domestic growth and developmental modernization. Yet paradigms in urban geography are precisely those whose appropriation Tang has cautioned us to assess. This is not a matter of internecine politics in the discipline or urban studies: in the humanities and social sciences at large, since the spatial turn, multiple disciplines and various interdisciplinary projects have routinely idea-borrowed from currents in geographical thought.

How paradigms gain institutionalization in research design depends on the mutually constitutive process of adoption and circulation among knowledge communities. Kuhn's treatment of scientific practice and scientific breakthroughs demonstrates the significance of the social in the pursuit of science. Kuhn observes how paradigms circulate through scholarly networks that assiduously adopt and promote particular models and approaches. Contrary to principles of scientific practice, Kuhn finds, research networks reproduce paradigmatic models more than they actually test their elements. These networks and groups may not even be likeminded, yet contend over the same model. Developing new ones is typically not the priority.

We see this situation in the journal literature, in which academics debate details of each other's work. In one memorable case, Neil Brenner, focused on the primacy of capitalism in dynamic rescaling, importunely critiqued the dimension of household economy that Sally Marston brought to the subject. Mark Purcell coined the phrase "island of practice" to characterize the Marston/Brenner debate because, instead of advancing the scholarship, it produced "nonengagements." Purcell writes, identifying the 
problem of discrete paradigmatic worldviews, such islands "close down analysis so that scholars have difficulty seeing past their particular focus" (Purcell 2003, 328). He urges development of a synthetic geography that would collaborate across research subfields. Kuhn, in reflection on the general issues and longer-term implications for the quality of knowledge production, developed the thesis that scientific breakthroughs more often appear in the work of relatively independent scholars who pursue original projects.

In response to his original thesis, Kuhn (1970) subsequently defined two kinds of paradigms, the "exemplar" and the "disciplinary matrix." The matrix constitutes the broader knowledge of the discipline whereas the exemplars are specific models. The particular problematic for scholarship on urban China is the circulation of exemplar paradigms. In practice, it works like this: an exemplar paradigm modeled on the history of cities in western Europe or the United States, for instance, circulates through scholarly adoption and publication to model places with histories that are not based on historical political-economic liberalism. The exemplar paradigm does its incremental analog work by masking the crucial issue of consequential differences between place of origin and the place of application. The disciplinary coup de grace is the chorus of complaint that differences in the political economy of urban institutions do not really matter if we are interested in the realities of general change in the contemporary world economy. Alan Scott's work on the city-region, for example, based on economic and population agglomeration, demonstrates this tendency (e.g. Scott 2019).

The problem of analog circulation is by no means new. Indeed, it constituted a short-lived explicit research approach. Andrew Mair, a student of Kevin Cox, spotlights the history. In dialog with Kuhn, Mair identifies how the "exemplar method," 
transmuting "a pedagogic as well as a heuristic role," uses "solutions to past problems in order to account for new situations" but "without recourse to explicit correspondence rules or even empirical generalizations" (Mair 1986, 351). He continues, "a subset of analogical arguments is uniquely geographic; the application of analyses derived in one place to new situations in other places" (360). For instance, Mair identifies in Michael Woldenberg's and Brian Berry's (1967) attempt to compare river systems and central place systems a "stillborn" effort with "little positive content." Woldenberg sought to model "persistent geometric progressions" of "mathematical regularities" in physical, human, and biological forms. In addition to attempting to naturalize market economies, i.e. comparison of central place systems and river systems, Woldenberg $(1979,429)$ proposed comparison of "trees, blood vessels, airways, bile ducts and even the microscopic branching of the Purkinje cell in the brain." The faulty logic on display is the one in which would-be similar patterns are held to be significant and explicable by mathematical generalization. The analog approach seeks to identify regularities of similar order — similar forms, patterns, structures and internal arrangements. Self-evident problems - great leaps among subjects and domains characterized by widely if not wildly different conditions_- confirm the unsound analog method.

Such illogic also appeared in the field of spatial science in the postwar era. In deservedly limited research on "social physics," the laws of physics were applied to social change. Trevor Barnes explains the analog: based on Newton's gravity model, researchers "assumed that humans interact over space as heavenly bodies do in the celestial system" (Barnes 1994, 567). There is the laughable element, but the fundamental scientific problem is faulty analog reasoning. 
In more recent work, Giorgio Agamben (2009) too observes how analog circulation limits the quality of exemplar models in research design. Instead of working to inform deductive and inductive reasoning between the general and particular, the sine qua non of geographical research, the exemplar paradigm as analog becomes, through iterative repetition, a singularity that fixes paradigmatic meaning. Regular analog exposition constitutes its intelligibility: a model becomes popular because it has become well known, not because it is necessarily epistemologically sound, scientifically tested, or adjusted and changed in relation to new discoveries.

In urban geography and comparative urban studies, the concept of gentrification exhibits analog circulation. Until just over a decade ago, gentrification research focused on the U.K. and North America, with disproportionate work on London and New York. Since then, the concept has spread while generating debate over its meanings, utility, and effectiveness. Among other issues, it stretches awkwardly to grasp realities where the state takes a leading role in redevelopment of the city. Scholars of China, Hong Kong, and Singapore, for example, find its conceptual elements lack capacity to handle structural conditions of historical land development (Tang 2017) in addition to the multiple roles of the state in the redevelopment of urban housing (Haila 2017; Tomba 2017).

Debate over the gentrification concept also extends to analog plays in the international academy. For example, scholars of gentrification "call for" gentrification research to be extended globally (Lees 2012; Ley 2014). On one hand, such efforts represent concern for serious urban issues as if neglected. On the other, they can suggest academic hegemony as if research on urban redevelopment, class, and inequality is 
lacking "elsewhere." In my analysis of the issue, it became apparent that David Ley, who suggested gentrification was effectively "missing" in Hong Kong, had both overlooked existing scholarship while overstating the appearance of gentrification in various national conversations (Cartier 2017).

Promotion of the English language word gentrification, globally speaking, resonates with disciplinary theory's disappearance of inconvenient empirics. Attempts to promote gentrification exhibit analog circulation, as well as invite postcolonial critique of the apparent paradox: "western" or "northern" scholars claim some "lack" elsewhere while lacking knowledge of existing research in "other" academies. Existing postcolonial critique calls this move epistemic violence. I would like to draw on Chinese-language phraseology and call it the "double-lack." Indeed, theoretical advances in geography, leading the spatial turn, also addressed such inequities in the international academy. We have to be vigilant. My main concern about this kind of analog borrowing is its capacity to occlude from research inquiry actual causal processes at stake.

The problem of analog properties for geographical exemplars is their application to apparently "like" places, places that the exemplar was not developed to theorize. Consider the "global city" as a paradigm, based on the work of Saskia Sassen for London, New York, and Tokyo. A certain amount of debate has demonstrated the limitations of treating Tokyo as a global city by comparison with London and New York (White 1988, 2011). The comparative scholarship on China has predictably sought to examine Shanghai as a global city. A relatively new financial district of super-tall buildings commands Shanghai's urban landscape, generating the appearances of a global city. But the substantial scholarship on the structural conditions of the Shanghai economy 
finds them to be sufficiently different from those of London and New York to conclude that Shanghai does not share diagnostic global city conditions ( $\mathrm{Li}$ and $\mathrm{Wu} 2006)$. The central government of China directly administers Shanghai, whose conditions differ in key ways from assumptions about capitalist rescaling and global networks (Cartier 2015). The global city concept gained altitude through worlding discourses, while the realities of some major cities are only refracted through its lens.

The problems of the exemplar for urban geographies in China can be resolved only partially through critique of theory. Varieties of urban theory, whether neoclassical (spatial science), Marxist (the urban process), or neoliberal (politics of scale), all based on the capitalist city in Europe and North America, tend not to incorporate geographies of power. As John Allen (2003) has demonstrated, varieties of power tend to be "lost" in capital-centric thought. Resting on the history of political-economic liberalism, varieties of urban theory do not reliably bring into view the absences they otherwise generate, including the many powerful roles of the party-state governing urbanization in China. Urban theory tends to reproduce the capitalist aesthetic — ideas about and materializations of the circulation of capital. And yet we cannot simply call this a problem of western theory because research on urban transformation in the Chinese academy has also hewn to normative international paradigms. If geographers and scholars in the Chinese academy have also adopted so-called western theory, then the problem is not the West perforce; the problem is inextricably bound-up with the expansion and internationalization of academic work in and about China and Asia at large.

One line of response appears in the analysis developed by Chan and Wei (2019), in this issue, on the origins of the Mao-era rural-urban dual system in the Soviet Union. 
The Soviet Union first developed the rural-urban dual system in which agricultural productivity was siphoned off to support urban-industrial development through collectivization, state procurement, and limits on rural-urban migration. This dual system organization transferred to China during the 1950s when the Soviet Union advised the PRC. The hukou system and the land use system in China today derive from the Soviet model. However, comparative analysis of this significant history appears infrequently in scholarship. The article by Chan and Wei is the first in a geography journal to analyze the political-economic origins of the Chinese socialist economy in the Soviet system. This reality contributes another paradoxical question to our concerns: why do paradigms adopted for research on China derive more often from the experience of the urban process under capitalism rather than its legacies and transformations from the history of the planned economy under socialism?

\section{Models and modeling achievement}

In late 2012 the international news media ricocheted with reports of the largest building in the world by floor area about to be opened in Chengdu, the next in a long line of "largests" in China's cities. Thomas Campanella, in The Concrete Dragon, chronicles the "sheer audacity" of it all in terms of Schumpeter's creative destruction: "Bigness and supersized sprawl may have once been American specialities, but that monopoly has been usurped" (Campanella 2008, 14-15). The words market and capitalism feature liberally in his narrative, but socialism appears as only a vestige of the past. Campanella strikes the common equation between the spectacular built environment in China, cities, and capitalism. 
Yet the distinctiveness of the Chengdu project resonates with Tao Zhu's diagnostic of the socialist built environment in China since the 1950s-"building big, with no regret" (Zhu 2011). In 1958-59, in a little over a year, the Party and the central government led the construction of the Ten Great Buildings in Beijing, which included the Great Hall of the People, Beijing Railway Station, and the National Museum of China to commemorate the 10th anniversary of the People's Republic of China. In recent years, rapid construction of large-scale built environments, including infrastructure systems, has become as if diagnostic of China's economic growth in recent decades. But the scale of the projects continues the history of state-led construction under socialism.

Direct comparisons exist in the history of Soviet planning. In the Soviet era, massive infrastructure construction was called "total planning" for simultaneous planning of the economy and society. The Soviet leadership, Stephen Collier $(2011,38)$ recalls, sought rapid industrialization through "city-building" or gradostroitel'stvo, which was not limited to the construction of new cities. It was the general program for coordinating the populations and the political economy for industrial modernization. It sought to "revolutionize the national population's conditions of existence, first of all by rearranging it over national space" (49). This is the city-space of the socialist state's telos of planning - the space economy of the state's idealized future in urban form. This role of the city in total planning has re-emerged in China, not only for urbanization but also scientific modernization and general social and economic development.

In work on the built environment, Bianca Bosker (2013) asks why so many urban development projects with self-consciously iconic buildings reproduce western architectural forms. The seven versions of the Eiffel Tower in China are only some of the 
most recognizable among imitation structures and places, which include numbers of White Houses, Venices, and Versailleses in addition to Disneylands. In analog circulation, based on precepts of the exemplary model, any one of the replica Eiffel Towers in China may be read less as a kitschy copy than a model of iconicity. Bosker draws on Chinese aesthetics to venture that architectural copies should be understood in relation to Chinese art and imperial microcosms. In Chinese painting, for example, good imitation of an existing work, demonstrating inspired interpretation, is to be well regarded. Thus what is the local quality of the Tower Bridge replica in Suzhou? Is it a good rendition, well built and the well situated? Bosker also considers the role of imperial microcosms to resituate interpretations of space and place. China's imperial gardens, stocked with representative flora and fauna from across the empire, constituted microcosms of imperial rule. Wealthy merchants built their own, in a manner of landscape appropriation, which symbolized legitimacy. After the PRC opened to the world economy, property developers built replicas of iconic foreign places that the new Chinese consumer-citizen, now imagining globally, would seek to experience. This arguably closer relationship between reality and representation in Chinese aesthetics, including architecture and landscape design, influences perceptions of places-making copy architecture another exercise in space-time distanciation.

\section{Exemplarity at large}

Exemplary models have a long history in China, but the notion of the CCP promoting didactic models for citizen socialization tends to be associated with the Mao era. However, the Party has revived didactic models in recent years in association with 
scientific development, including models of exemplary human conduct and places of exemplary development. Through the circulation of exemplary models, now in the name of science, the party-state conveys of what it approves and seeks to socialize commensurate conduct.

In The Exemplary Society, Børge Bakken examines the revival of models, called moshi 模式 or mofan 模范, of people and places and moral models or daode mofan 道德模 范 in relation to scientific development and modernization. Exemplary models constitute elements of "the 'scientific' approach to human and social improvement," writes Bakken $(2000,30)$. Exemplary persons range from contemporary leadership figures to Mao-era socialist avatars and modern representations of Confucius. In recent decades, the "models should reflect modern values, with the fixity of the traditional exemplary model loosened up in order to adapt to the changing times." What has changed is the "scientification of exemplarity, for the production of norms and standards to be carried out in a far more systematic and scientific manner" (Bakken 2000, 217). In turn, the scientification becomes institutionalized through "a methodology of spiritual civilization based on the scientific production of norms and standards." Here we see the meta-concept of civilization, which appears uniformly in governing institutions, including city governments, schools and workplaces. The party-state has renovated the significance of models for precepts of modern scientific development.

Behavioral models trace to the tradition of scholar-officials as exemplars of learning and leadership (Munro 2000), yet the compelling matter is how and why these models continue and transform. In the 1940s, the CCP introduced the Stakhanovite labor mobilization model from the Soviet Union to promote zealous work activity (Funari and 
Mees 2013), and subsequently portrayed the urgency of socialist production through model places for agricultural and industrial development, uniting workers at the grassroots (Shapiro 2001).

Since the 2000s, models of both people and places have been revamped for the urbanization drive. The scientific model of human transformation appears in a biopolitics of human "quality" or suzhi 素质 that would modernize populations for rapid urbanization (Anagnost 2004). The party-state also seeks the people's urgent cooperation for consumer capitalism, even reviving the visage of Lei Feng, Mao's hagiographical loyal soldier and model super-citizen — representing selfless relations between the people, the CCP, and the People's Liberation Army—for placement on personal consumption items. Lei Feng may be the most obvious symbol of party propaganda, but the subject of Lei Feng features in more than 11,000 journal articles in the Chinese academy since 1963. "In recent decades," Perry Link (2015, 27-28) writes, “Chinese Communist Party leaders have tried to revive the traditional moral-political model with certain modern adaptations" based on attaining the "Chinese dream" of wealth and power through "a 'Chinese model' of development.” The renewed approach to exemplarity bridges party leadership with national development to hold out the ideal of a better life for the people, albeit now relentlessly based on consumer modernity.

In the second half of the 1990s, the improvement of urban governance for cities in China emerged in the form of model city award programs. The National Environmental Protection Model City award program started in 1997, followed by model city awards for everything from managing public security and quality of general hygiene, to innovation in science and technology and more. The pre-eminent model program, the National 
Civilized City, recognizes general urban governance based on measurable standards in multiple categories. It combines party priorities for official rectitude, which have intensified since 2012, with measurable governing targets, including environmental quality, the provision of cultural facilities, and food security. But its origins lie in spiritual civilization thought work. In the late 1990s the Party established the Spiritual Civilization Committee, under its Propaganda Department, also known by its official contemporary translation, the Publicity Department, which established and continues to administer the National Civilized City award program (Cartier 2013). The program links model conduct of party officials with urban improvement, making the honorific title contingent on exemplary leadership. It is, in a Foucauldian vocabulary, a technology of governmentality for coordinated governance. Its objective measures of assessment would raise scientific management over political favoritism. Continuing to hold the title requires periodic reassessment, entraining the city in a future-oriented programmatic of striving to improve. Commensurate with PRC's interest to enter world rankings on all fronts, from world-leading productive capacity to world-class cities and universities, the National Civilized City award projects a future nation of uniformly "civilized" places.

\section{Zone analog}

Perhaps the most successful analog in the history of the reform era is the simple concept of zone and its debut as the Shenzhen "special economic zone." The PRC opened to the foreign direct investment through Shenzhen, on the border of Hong Kong, placing an anchor on the edge of the harbor of global capitalism. As Hong Kong capital and manufacturing expertise crossed to Shenzhen, seeking lower costs of production, the new 
industrial economy grew quickly. And so international economic interest trained attention on Shenzhen, generating new narratives about "miracle" zones. In the process, the notion of a special economic zone became a space of capital circulation, a set of assumptions about economic growth, and a would-be policy approach.

Yet despite the inherent spatiality at stake, the scholarship on zones has often treated their geographies as once established and fixed, and then as sites where labor and capital jostle for product and accumulation (Cartier 2018). Aihwa Ong sought to retrieve their dynamics through "zoning" as "spaces of political and economic exception" (Ong 2004, 70; cf. 2006, passim). The suggestion that these areas exist as if apart from state territory facilitated the notion of "zone as exception" as an emerging paradigm. But a zone in China is only a selective translation of different types of administrative divisions. In China’s system of administrative divisions, in Chinese, xingzheng quhua tixi 行政区划 体系, the third character, $q u$ 区, means area, district, region or zone. The full sweep of China's subnational territory exists within this system. No areas are excepted from its system of territorial governance, just as there are no unincorporated areas.

The primary institutional category of a special economic zone, in Chinese jingji tequ 经济特区 or “economic special district," is an administrative division of Chinese state territory. But the notion of exception would lead Ong to portray these administrative areas as if autonomous. "In short, the coastal zone authorities and open cities are spaces of exception to the centrally planned socialist economy. They enjoy autonomy in all economic and administrative matters" (Ong 2004, 81; 2006, 108). This notion of autonomy conveys the zone's capitalist aesthetic. Here Ong conflates opportunities for workers and firms with the administrative ontology and governing institutions of state 
territory. In reality, Shenzhen was first established as a sub-provincial-level city, and then given designated economic functions by the Chinese central government. Like any other subnational territory in the PRC, so-called zones are territorial governing areas under the jurisdiction of and directly governed under the authority of party committees. By institutional definition, none have autonomy.

Nevertheless, propelled by analog logic, the idea of special zones as if solutions to economic problems began to travel. The economist Barry Naughton identified the issue. Naughton $(2009,3)$ asks, "What Chinese institutions can we recommend for adoption by other developing or transitional economies?" "None," yet "we must deal with one apparent exception. Hasn't the Chinese policy of Special Economic Zones (SEZs) been replicated around the world?" "What is most innovative about Chinese SEZs is size, multi-functional use as a laboratory of multiple types of reforms, and openness to the domestic economy" which makes them actually "not a good candidate for replication." Here Naughton identifies the analog problem. Instantiated within the PRC territorial system, the SEZ is not a good candidate for international replication since it is a partystate project with state-allocated budget and exceptional powers of authority, in addition to area size on the scale of entire cities and regions. When India, for instance, sought to model China's zones, it realized their scale and scope could not be matched (Sharma 2015).

The local differences of regional development have also been expressed in the language of models. Substantial discussion takes place in China over the various merits of economic development in the provinces (e.g. Xin and Liu 2001; Song 2009). Analysts of regional development identify and debate some ten different models, while three major 
models have dominated the conversation: the Su'nan, Zhujiang, and Wenzhou models. Here the word model is also commensurable with the relatively routine discourse of international political economy. Yet its valences are more complex, linking to the broader cultural-historical discourse of exemplary practices in China.

During 2010-2012 a new discourse of regional models emerged in a competitive dialog between the party leaders of Guangdong and Chongqing (Cartier and Tomba 2012). Splashed across the media, this "cake debate" parsed comparative merits of the size, portions, and distribution of economic resources (in China, cake is better than pie). The Guangdong model would reenergize marketization for new rounds of growth, whereas the Chongqing model would continue state-owned enterprises and emphasize redistributive measures including social housing. But the popular and policy discourses of the Chongqing model began to fade, after March 2012, when the party leader of Chongqing was removed from power. To oversee the political transition, the central government assigned Zhang Dejiang, the former governor of Guangdong province, to Chongqing. In response to questions at the 18th Party Congress, Zhang (2012) stated, predictably, "I think fundamentally there is no Chongqing model." But issues at the heart of the cake debate characterize ongoing issues of socio-economic inequality in China.

\section{The "loss of space"}

Exemplary models continue to circulate in China. Some play significant roles in the urban process. Others, like Lei Feng, are targets for jokes. Nevertheless, from historical personages, to contemporary party policy programs and expressions of regional development, the multiple forms of the exemplary model testify to their prevalence. 
These models, like paradigms, circulate through information networks, and are by definition forms of both ideology and practice. They materialize in places and some, like the awards for good governance, influence the transformation of the city. They are partydefined techniques of governmentality, working to show the acceptable ontological range for people and places under unitary state formation. Characteristic of and transcending the socialist era, models in China's culture and politics are also deeply historic in form and substance. Even as disciplinary paradigms do not facilitate research on these exemplars, their existence and analog circulation point paradoxically to the general problem of analog models in the international academy. And the word model itself, at once common and scientific, camouflages the intermediating political work the analog accomplishes, not only in China.

If exemplary models in China foreground contexts of party-state approval, what do they leave out? In general, the exemplar paradigms for urban research lack capacity to conceptualize the state structure of the urban process in China. Acknowledgement of this realization has taken a long time to emerge. A main reason why is that China's opening to the world economy converged with late capitalism's trajectory of neoliberalization, which co-generated widespread assumptions about decentralization and marketization. The neoliberal critique, circulating as a kind of free radical of theory, also attached to urban China geography. But it has lacked the capacity, for instance, to conceptualize party-state power relations in China's urban development. Indeed, with concern about the limits of the neoliberal thesis for understanding cities in Russia, Collier (2011) turned to examine the continuities of Soviet planning history. In addition, the scale relations paradigm, generated from work on state rescaling under advanced capitalism, has also 
fallen short, not least because its elements do not conceptualize rank relations of the Chinese state structure. In an article on the recentralization of power over city-regions in China, Wu Fulong $(2016,1151)$ rehearses the international rescaling approach only to ultimately conclude "Chinese state dominance in governance is distinctively different from Western and other non-Western contexts," yet without causal or historical analysis. Here is the realization that Wing Shing Tang identifies and articulates.

Conjunctures emerge among different kinds of models and standards. Striving for city recognition in China, from outsize construction projects, to economic productivity and urban quality awards, also appears prominently in China's education sector. Since the 2000s, the PRC Ministry of Education has worked to vault the leading universities into the higher echelon of world rankings (Wang, Wang and Liu 2011; Ministry of Finance 2012). Within the university, the institutional remit incentivizes research productivity, including requirements for international English-language journal publications. In the process, the Chinese academy has directly linked its universities to the peer-review journal process, driving the conjuncture between the Chinese academy and the international academy. This process contributes to intensifying the circulation of exemplar paradigms.

Now the consequences become clearer. The top-down directive for scientific research pressures adoption of international paradigms. The use of exemplar paradigms for journal publication, entrained in national scientific development, becomes routine. The practice contributes to national legitimacy, even as it works to bracket original approaches in addition to existing realities or empirical conditions that do not "fit" the models. In this dialectic, the circulation of exemplar paradigms comes to serve the state, 
by simultaneously enhancing international legitimacy, yet through use of models that do not investigate it. The sum total of these operations diminishes the potential for original work and the insights it would generate. We have a concentration of research approaches that has been limiting understandings of the urban process in China-the annihilation of "space" by analog circulation of exemplar paradigms.

International paradigms in urban studies, based on fundamentals of economic liberalism, typically background the role of the state. For research on China, this reasonably well-known problem has been attributed to the notion of "sensitivity" about the political system, generating some compliant ignorance about it. However, this socalled black box, as if containing the party-state from inquiry, has become a false proposition. The CCP itself says so. In 2015 the Chinese state media announced "Chinese Communist Party publishes ‘self-decoding’ series for Western audience.” This Xinhua (2015) headline describes the CCP's "move to reach out to the Western audience to help them understand why it remains the single, largest ruling party" through a series of books. The five English-language volumes, launched in New York City at a major publishing fair, constitute the Party's self-introduction to the world.

Analysis of multiple interrelated conditions about the uses of paradigms, in pursuit of scientific legitimacy, demonstrates why research on urban China has depended on exemplars, and how their uses limit ways of seeing. Their widespread adoption has precipitated a method of matching data and information. Neoliberalization of the academy, with normative science linked to academic promotion and national standing in the international academy, has intensified the practice. Even would-be expert research paradoxically disregards information and knowledge that is not commensurable with 
prevailing paradigms. These issues, characteristic of geography's scientific genealogy and the roles of science in industrial modernization, are not new. But they have arguably expanded in scale and scope. The consequential "loss of space" emerges just when China's extraordinary transformation wants for substantial documentation. At best, like the zone exemplar, the priority of market-based paradigms has been telling the story of the state only in terms of the market. Can we restore a fuller appreciation of urban China?

\section{Acknowledgements}

Funding from the Australian Research Council Discovery Projects (DP120101901, DP170100871) made possible the research for portions of this work. I owe particular thanks to Kam Wing Chan, Tim Oakes, and Wing Shing Tang for discerning suggestions on drafts of the paper. I also thank Michael Somers for reading and editing the manuscript and urging further development of its ideas. My work on paradigms and inter/disciplinary history reflects earlier intellectual support from three key scholars. The imprimatur of the historian Frederic Wakeman for reevaluation of the macroregion model mattered pivotally. Enthusiastic regard for the geographical critique from Neil Smith lent a significant dose of predictably undaunted resolve. And Geremie Barmé's shared grasp of civilizational thought contributed to ideas about reassembling the city.

\section{References}

Agamben, Giorgio. 2009. The Signature of All Things: On Method. New York: Zone Books. 
Agnew, John. 1987. Place and Politics: The Geographical Mediation of State and Society. Boston: Allen \& Unwin.

Allen, John. 2003. Lost Geographies of Power. Oxford: Blackwell. Atkinson, Richard C. and William A. Blanpied. 2008. "Research Universities: Core of the US Science and Technology System.” Technology and Society 30 (1): 30-48.

Bakken, Børge. 2000. The Exemplary Society: Human Improvement, Social Control and the Dangers of Modernity in China. Oxford: Oxford University Press.

Barnes, Trevor J. and Claudio Minca. 2012. "Nazi Spatial Theory: The Dark Geographies of Carl Schmitt and Walter Christaller." Annals of the Association of American Geographers, 103 (3): 669-687.

Barnett, Clive. 1998. "Impure and Worldly Geography: The Africanist Discourse of the Royal Geographical Society, 1831-73." Transactions of the Institute of British Geography NS 23: 239-251.

Bosker, Bianca. 2013. Original Copies: Architectural Mimicry in Contemporary China. Honolulu: University of Hawaii Press.

Brady, Anne-Marie. 2008. Marketing Dictatorship: Propaganda and Though Work in Contemporary China. Landham, MD: Rowman \& Littlefield. 
Campanella, Thomas. 2008. The Concrete Dragon: China's Urban Revolution and What it Means for the World. Princeton, NJ: Princeton University Press.

Cartier, Carolyn. 2002. "Origins and Evolution of a Geographical Idea: The Macoregion in China." Modern China 28 (1): 79-112.

Cartier, Carolyn. 2013. "Building Civilised Cities” in China Story Yearbook 2013:

Civilising China. Canberra: The Australian Centre for China in the World, 256-285.

Cartier, Carolyn. 2015. "Territorial Urbanization and the Party-state in China." Territory, Politics, Governance 3 (3): 294-320.

Cartier, Carolyn. 2017. “Contextual Urban Theory and the 'Appeal' of Gentrification: Lost in Transposition?" International Journal of Urban and Regional Research 41 (3): 466477.

Cartier, Carolyn. 2018. “Zone Analog: The State-Market Problematic and Territorial Economies in China." Critical Sociology 44 (3): 455-470.

Cartier, Carolyn and Luigi Tomba. 2012. "Symbolic Cities and the 'Cake Debate" in China Story Yearbook 2012: Red Rising, Red Eclipse. Canberra: The Centre for China in the World, 25-52. 
Chan, Kam Wing and Yanning Wei. 2019. “Two Systems in One Country: The Origin, Functions, and Mechanisms of the Rural-Urban Dual System in China.” Eurasian Geogaphy and Economics.

Collier, Stephen J. 2011. Soviet Social Modernity: Neoliberalism, Social Modernity, Biopolitics. Princeton, NJ: Princeton University Press.

Cooper, Frederick and Randall Packard. eds., 1997. International Development and the Social Sciences: Essays on the History and Politics of Knowledge. Berkeley, CA: University of California Press.

Dirlik, Arif. 1996. "Reversals, Ironies, Hegemonies: Notes on the Contemporary Historiography of Modern China.” Modern China 22 (3): 243-284.

Farquhar, Judith B. and James L. Hevia. 1993. "Culture and Postwar American Historiography of China." positions 1 (2): 486-525.

Funari, Rachel and Bernard Mees. 2013. "Socialist Emulation in China: Worker Heroes Yesterday and Today. Labor History 54 (3): 240-255.

Geiger, Roger L. 1993. Research and Relevant Knowledge: American Research Universities since World War II. New York, NY: Oxford University Press. 
The Geographical Society of China (2018) "Introduction to the Society." http://www.gsc.org.cn/channel.aspx?id=5 Accessed Aug. 8, 2019.

Haila, Ann. "Institutionalization of the 'Property Mind'." International Journal of Urban and Regional Research, 41 (3): 500-507.

Harvey, David. 1978. “The Urban Process under Capitalism: A Framework for Analysis." The International Journal of Urban and Regional Research 2 (1-3): 101-131.

Hirsch, Francine. 2005. Empire of Nations: Ethnographic Knowledge and the Making of the Soviet Union. Ithaca, NY: Cornell University Press.

Hudson, Brian. 1977. "The New Geography and the New Imperialism: 1870-1918." Antipode 9 (2): 12-19.

Lees, Loretta. 2012. "The Geography of Gentrification: Thinking through Comparative Urbanism." Progress in Human Geography 36 (2): 155-171.

Ley, David, and Sin Yih Teo. 2014. "Gentrification in Hong Kong? Epistemology vs. ontology." International Journal of Urban and Regional Research 38 (4): 1286-1303.

Li, Zhang. 2002. Strangers in the City: Reconfigurations of Space, Power and Social Networks within China's Floating Population. Stanford, CA: Stanford University Press. 
Li, Zhigang and Fulong Wu. 2006. "Socioeconomic Transformations in Shanghai (19902000): Policy Impacts in Global-National-Local Contexts.” Cities, 23 (4), pp. 250-268.

Link, Perry. 2015. "What it Means to Be Chinese." Foreign Affairs 94 (1): 25-31.

Martin, Geoffrey J. 2015. American Geography and Geographers: Toward Geographical Science. Oxford: Oxford University Press.

Ministry of Finance. 2012. "Report on the Implementation of Central and Local Budgets for 2011 and on Draft Central and Local Budgets for 2012," Fifth Session of the Eleventh National People's Congress, March 5, 2012.

http://online.wsj.com/public/resources/documents/2012NPC_FinanceWorkReport_Englis h.pdf. Accessed Aug 8, 2019.

Mullaney, Thomas S. 2010. Coming to Terms with the Nation: Ethnic Classification in Modern China. Berkeley, CA: University of California Press.

Munro, Donald J. 2000. The Concept of Man in Contemporary China. Ann Arbor, MI: Center for Chinese Studies, University of Michigan.

Naughton Barry. 2009. “Singularity and Replicability in China's Developmental Experience. China Analysis 68: 1-22. 
Oakes, Tim. 2019. “China’s Urban Ideology: New Towns, Creation Cities, and Contested Landscapes of Memory." Eurasian Geography and Economics.

Ong, Aihwa. 2004. "The Chinese Axis: Zoning Technologies and Variegated Sovereignty." Journal of East Asian Studies 4 (1): 69-96.

Ong, Aihwa. 2006. Neoliberalism as Exception: Mutations in Citizenship and Sovereignty. Durham, NC: Duke University Press.

Purcell, Mark. 2003. "Islands of Practice and the Marston/Brenner Debate: Toward a More Synthetic Critical Human Geography.” Progress in Human Geography, 27 (3): $317-332$.

The Royal Geographical Society (n.d.) "The Society: History of the Society." http://www.rgs.org/AboutUs/History.htm. Accessed Aug. 1, 2019.

Schulten, Susan. 2001. The Geographical Imagination in America, 1880-1950. Chicago: The University of Chicago Press.

Scott, Alan. 2019. “City-regions Reconsidered." Environment and Planning A, 51 (3): $554-580$. 
Sharma, Mihir S. 2015. Restart: The Last Chance for the Indian Economy. Gurgaon, Haryana: Random House India.

Smith, Neil. 2004. American Empire: Roosevelt's Geography and the Prelude to Globalization. Berkeley, CA: University of California Press.

Song Linfei. 2009. 'Zhongguo 'Sanda Moshi’ de Chuanxin yu Molai (The Innovation and Future of China's 'Three Major Models').” Nanjing Shehui Kexue (Nanjing Social Sciences): 2009 (1): 1-6.

Tang, Wing Shing. 2014. "Governing by the State: A Study of the Literature on Governing Chinese Mega-cities” In Branding Chinese Mega-Cities: Strategies, Practices and Challenges. Edward Elgar, Cheltenham, 42-63.

Tang, Wing Shing. 2017. "Beyond Gentrification: Hegemonic Redevelopment in Hong Kong.” International Journal of Urban and Regional Research, 41 (3): 487-499.

Tomba, Luigi. 2017. Gentrifying China's Urbanization? Why Culture and Capital Aren't Enough. International Journal of Urban and Regional Research, 41 (3): 508-517.

Walder, Andrew. 2004. "The Transformation of Contemporary China Studies," in The Politics of Knowledge: Area Studies and the Disciplines. Berkeley, CA: University of California Press, 314-340. 
Wang, Qing Hui, Qi Wang and Nian Cai Liu. 2011. "Building World-Class Universities in China: Shanghai Jiao Tong University" in The Road to Academic Excellence: The Making of World-Class Research Universities. Washington, D.C.: The World Bank, 3351.

White, James W. 1998. “Old Wine, Cracked bottle? Tokyo, Paris, and the Global City Hypothesis." Urban Affairs Review 33 (4): 451-477.

White, James W. 2011. Mirrors of Memory: Culture, Politics, and Time in Paris and Tokyo. Charlottesville, VA: University of Virginia Press.

Wimmer A and Schiller NG (2002) "Methodological Nationalism and Beyond: Nationstate Building, Migration and the Social Sciences." Global Networks 2 (4): 301-334.

Wu, Fulong. 1997. “Urban Restructuring in China’s Emerging Market Economy: Towards a Framework for Analysis." International Journal of Urban and Regional Research 21 (4): 640-663.

Wu, Fulong. 2016. “China’s Emergent City-Region Governance: A New Form of State Spatial Selectivity through State-orchestrated Rescaling." International Journal of Urban and Regional Research 40 (6): 1134-1151. 
Wu Zhong. 2011. “New Leftists Salute Wall Street Brethren,” Asia Times Online, 13 Oct. 2011. http://www.atimes.com/atimes/China/MJ13Ad01.html. Accessed Aug. 1, 2016.

Xin, Wang and Liu Qihong. 2001. "Sanda Moshi, Hequhecong (What Lies Ahead for the Three Major Models).” Zhongguo Jingji Kuaixun (China Economic News), 2001 (29): $13-17$.

Xinhua. 2015. “Chinese Communist Party Publishes 'Self-decoding' Series for Western Audience," May 29. http://en.people.cn/n/2015/0529/c90777-8899515.html. Accessed Aug. 8, 2019.

Xinhua. 2018. "China Focus: Xi Calls for Developing China into a World Science and Technology Leader,” May 29, http://www.xinhuanet.com/english/201805/29/c_137213175.htm. Accessed Aug. 8, 2019

Yang, Mayfair, ed. 1999. Spaces of Their Own: Women's Public Sphere in Transnational China. Minneapolis, MN: University of Minnesota Press.

Zhang, Dejiang.2012. “Zhang Dejiang: Wo Renwei Genben Jiu Bu Cunzai Chongqing Moshi”(Zhang Dejiang: I Think Fundamentally There Is No Chongqing Model)," Caixin, Nov. 8, 2012. http://china.caixin.com/2012-11-08/100458064.html. Accessed Aug. 8, 2019. 
Zhu, Tao. 2011. "Building Big, with no Regret." AA Files 63: 104-110. 